\title{
Banning the Ivory Trade in Hong Kong
}

A Review of the Local English-language Press

\section{Claire Bouillot}

\section{OpenEdition \\ Journals}

\section{Electronic version}

URL: http://journals.openedition.org/chinaperspectives/8509

DOI: 10.4000/chinaperspectives.8509

ISSN: 1996-4617

\section{Publisher}

Centre d'étude français sur la Chine contemporaine

\section{Printed version}

Date of publication: 31 December 2018

Number of pages: 65-69

ISSN: 2070-3449

\section{Electronic reference}

Claire Bouillot, "Banning the Ivory Trade in Hong Kong », China Perspectives [Online], 2018-4 | 2018, Online since 31 December 2019, connection on 24 March 2020. URL : http://journals.openedition.org/ chinaperspectives/8509; DOI : https://doi.org/10.4000/chinaperspectives.8509 


\section{Banning the Ivory Trade}

\section{in Hong Kong}

\section{A Review of the Local English-language Press}

\section{CLAIRE BOUILLOT}

T he date of 31 January 2018 marked the adoption in Hong Kong of a three-phased law banning trading in elephant ivory that will come into full effect on 31 December 2021. (1) This follows the decision of mainland China outlawing this practice from 31 December 2017. These new ordinances, which derive from an international convention (CITES), ${ }^{(2)}$ are particularly adapted to these places as they represent (with Japan) the world's principal destination of ivory, both legal and illegal, and have done so since the 1950s (Barbier et al. 2009). This trade, and especially its illegal strand, threatens the survival of Africa's elephants, whose ivory is regarded as precious (Wittemyer et al. 2014; Thouless et al. 2016).

In Hong Kong, the movement of ivory is regularly in the news. July 2017 recorded the largest seizure of illegal ivory in the past 30 years (7.2 tonnes). (3) Early 2018 was also noteworthy on account of two events: on the one hand, the resignation of a member of the governmental consultative committee on endangered species (who is also an ivory trader), who had been selling illegal ivory, thus lending a whiff a scandal to the legislative process; ${ }^{(4)}$ and on the other hand, the despicable killing in Nairobi of Esmond Bradley Martin, one of the leading experts on the trafficking of ivory. ${ }^{(5)}$

These national and international events, together with scientific studies and various other reports, have been part of the context of legislative reform in Hong Kong. They are an indication of the complex nature of the issues involved, as can be seen in the stormy legislative debates brought about by competing interests. Quite a number of local newspaper articles (in English and Chinese alike), as well as the (English-language) press in mainland China, have covered this reform by exposing the tensions, divergent points of view, and arguments of the protagonists. It might still appear, however, that there has been little discussion of certain points. The present article will highlight, through an analysis of the media's treatment of the legislative reform process in Hong Kong, the political issues at stake in this ban, and in particular the grey areas of the public debate. It tries to break with the dichotomy "for" or "against" that are often typical of debates on the extinction of these emblematic mammals. In this press review I undertake a detailed analysis of local newspaper articles, essentially those of the English-language press. Of the 41 articles examined, I selected 21 on the basis of their relevance to legislative reform in Hong Kong and the diversity of their content. Two articles from the Chinese-language local press (selected from 28 articles), as well as six articles from the mainland's English-language press (selected from 47 articles) serve to underscore this analysis. These articles were published between 2015 and July 2018 , that is, from the announcement of the reform until its initial implementation. This article will refer to the timeline of the reform with respect to several key moments and questions that require particular attention.

\section{The inevitability of the reform}

In 2015, President Xi Jinping made a commitment to a progressive ban on the ivory trade in mainland China. ${ }^{(6)}$ In Hong Kong, the news was received as a positive sign of a future ban on trade on the island. ${ }^{(7)}$ Indeed, as early as January 2016, the then head of the Hong Kong Executive Council, Leung Chun-ying, announced his intention to shut down the market. A bill strengthening the previous provisions was drawn up in 2016, and subsequently debated in the Legislative Council in 2017 before being adopted on 31 January 2018. Whilst the reform was quickly ratified in the wake of mainland China's decision in this area, the newspaper articles do not highlight the connections between the two reforms, particularly the political dynamics in relation to governance issues. The conservation of African elephants through two similar ordinances would therefore seem to constitute a consensus between mainland China and Hong Kong. Whilst that may be good news for the species concerned, it does raise issues about the legislative autonomy of Hong Kong.

Similarly, one article characterises Leung Chun-ying's announcement as a "surprise." (8) This is remarkable, given that Hong Kong is a globally recog-

1. Protection of Endangered Species of Animals and Plants (Amendment) Ordinance 2018, The Government of the Hong Kong Special Administrative Region Gazette, https:/www.gld.gov.hk/ egazette/pdf/20182206/es1201822067.pdf (accessed on 10 July 2018).

2. Convention on International Trade in Endangered Species of Wild Fauna and Flora (CITES). The Convention, which came into force in 1975, was adopted by Hong Kong in 1976 and by mainland China in 1981. See https://www.cites.org/fra/disc/what.php (accessed on 15 February 2018).

3. Jun Pang, "In Pictures: 3 arrests as Hong Kong makes record ivory seizure totalling 7.2 tonnes," Hong Kong Free Press, 6 July 2017, https://www.hongkongfp.com/2017/07/06/three-arrestshong-kong-makes-record-ivory-seizure-totalling-7-2-tonnes/ (accessed on 19 july 2018).

4. Elson Tong, "Hong Kong trader caught with illegal ivory quits gov't endangered species advisory post," Hong Kong Free Press, 10 January 2018, https://www.hongkongfp.com/2018/01/10/hongkong-trader-caught-illegal-ivory-quits-govt-endangered-species-advisory-post/ (accessed on 19 July 2018).

5. Associated Press, ''A robbery made to look like a hit'? His work persuaded China to ban ivory trading - now he has been found stabbed to death at home in Kenya," South China Morning Post, 5 February 2018, https://www.scmp.com/news/world/africa/article/2132110/his-work-persuaded-china-ban-ivory-trading-now-he-has-been-found (accessed on 18 July 2018).

6. Andre Vltchek, "Ivory ban is an example for the world," China Daily, 12 January 2018, http://africa.chinadaily.com.cn/weekly/2018-01/12/content_35489543.htm (accessed on 24 July 2018).

7. Kylie Knott, "Is US-China deal enough pressure to push away Hong Kong's illegal ivory trade?", South China Morning Post, 26 September 2015, https://www.scmp.com/news/hong-kong/healthenvironment/article/1861714/pressure-halt-hong-kong-ivory-trade-increases (accessed on 21 September 2018).

8. Ernest Kao, "Hong Kong plan to ban ivory trade by 2021 receives Executive Council go-ahead," South China Morning Post, 21 December 2016, https://www.scmp.com/news/hong-kong/healthenvironment/article/2056411/hong-kong-plan-ban-ivory-trade-2021-receives (accessed on 12 July 2018). 
nised hub for the ivory trade (Barbier et al. 2009; Martin and Vigne 2015). Furthermore, ever since 2013 Hong Kong has been classified as one of the places most affected by illegal ivory trafficking in terms of the "National Ivory Action Plans Process" of the CITES. Another article states that Elizabeth Quat, a member of the Legislative Council who made a trip to Kenya in 2014, put forward a motion at a meeting of the LegCo in December 2015 with the aim of bolstering the fight against contraband in wild animals. ${ }^{(9)}$ Finally, it would seem that those working in the production of ivory and its trade have been consulted about this matter over "the past year or two" through the Agriculture, Fisheries and Conservation Department (AFCD), which issues licences for the importation, exportation, re-exportation, and sale of ivory in Hong Kong. ${ }^{10)}$

It is therefore clear that the reform was imminent. It had moreover been prepared as far back as 2013 by the institutions for the protection of wildlife, as well as by a whole range of actions aimed at raising the awareness of the public and legislators about the subject ${ }^{(11)}$ (the destruction in 2014 of seized stocks of ivory, investigations using secret cameras into the activities of traders in relation to ivory laundering, ${ }^{(12)}$ etc.). It would seem that these actions bore fruit, according to a WildAid commissioned study carried out in 2014. It concluded that $75 \%$ of those questioned in Hong Kong supported the banning of ivory trade (Pang 2015), which was then taken up as an argument in the Legislative Council.

\section{A concerted effort against the ivory trade}

This analysis of the media coverage reveals three types of actors involved in the power games around the ivory trade legislation. They overlap with the categories mentioned by Gao Yufang in the study of the banning of the ivory trade in mainland China: "anti-illegal trade," "pro-trade," "anti-all-trade" (Gao 2014). The first of these, "anti-illegal-trade," is made up of institutions that have led and implemented the reform (the governmental Office for the Environment, the Legislative Council, the AFCD). The second (in part "pro-trade" - some of those involved in the fabrication of ivory preferring to be referred to as being "anti-illegal trade") represents the 100 artisans and 370 ivory traders operating with a licence as collectives: ${ }^{(13)}$ the Hong Kong Ivory Manufacturing Workers General Union, the Hong Kong and Kowloon Ivory Manufacturers Association (Wong 2018), the Hong Kong Ivory Industrial and Commercial Association, and the Hong Kong Ivory Arts Association.

The third type of actor ("anti-all-trade") is embodied in the institutions for the protection of wildlife. WildAid is at the forefront of these, as it has shown itself to be very active in public debate, but its representative was only one of a dozen or more people invited to give evidence before the Legislative Council's panel on Environmental Affairs in June 2017. ${ }^{(14)}$

It is worth noting that some market players, the ivory buyers, who have varied backgrounds (ranging from amateurs to collectors), do not rate much of a mention in these articles. However, there are some motivating factors that might explain their positioning in the debate. For example, given that very old objects made of ivory increase in value due to the increasing scarcity of the substance, some collectors and investors have a financial interest in commercial banning, which would have the effect of making ivory even more precious. In failing to mention the buyers and the diversity of their interests, the articles elude certain questions linked to the demand for and appeal of ivory.

This reform is therefore mobilising actors with divergent interests, but a majority of them would seem to be in agreement on the principle of the ban itself, something that was confirmed by the final vote (49 in favour, with 4 against). The core motivation behind this trade ban, namely its positive effect on slowing down the poaching of African elephants, was certainly referred to by those who promoted the reform. However, in terms of press reporting there seems to have been little discussion of the matter. One article quotes an ivory trader who, as far back as 2016, characterised this reform as being "illogical": "If you stop the sales, will it really stop the killing of elephants in Africa?" (15) This question is worth raising. Researchers are in agreement on the fact that the ivory trade ban is not adequate. It must be followed by border control measures in both importing and exporting countries (and also be applicable to online trading), as well as measures aimed at eliminating corruption and providing education in order to change the appetite for ivory (Cornelis van Kooten 2008; Bennett 2015; Wong 2018). Furthermore, the question of continuing to allow legal trading, and therefore of preserving the value of ivory, is sometimes mentioned. ${ }^{(16)}$ It warrants further comment, however, as bans in ivory trading are never comprehensive. In Hong Kong, the sale of ivory objects made prior to 1 July 1925 (excluding trophies) will still be allowed, subject to control. While certain articles in the press refer to the trade in antiquities, the economic consequences of maintaining this part of the trade are not considered. ${ }^{(17)} \mathrm{How}-$ ever, ivory laundering is quite a common practice in Hong Kong (between ivory from elephant tusks and from mammoths, and between old and recent ivory - Knights et al. 2015), and in the absence of biological studies it is impossible to date the material with any certainty. These analyses are costly and have to be conducted abroad, as at present the Hong Kong authorities do not have sufficient instruments available to carry out proper quantitative or qualitative analyses. ${ }^{(18)}$ We may therefore wonder whether this niche will preserve a trade (illegal or otherwise) and maintain a value for ivory, all the more so in that states are implementing policies for the destruction of ivory

9. Koel Chu, "Motion to ban ivory trade to be discussed in LegCo," Hong Kong Free Press, 1 December 2015, https://www.hongkongfp.com/2015/12/01/motion-to-ban-ivory-trade-to-be-discussedin-legco/ (accessed on 19 july 2018).

10. Ernest Kao, "Hong Kong ivory traders mull legal challenge against plan to ban sales in five years," South China Morning Post, 26 December 2016, https://www.scmp.com/news/hong-kong/healthenvironment/article/2057272/hong-kong-ivory-traders-mull-legal-challenge (accessed on 12 July 2018).

11. Ernest Kao, "Why Hong Kong's ban on ivory trade is such a big deal," South China Morning Post, 2 February 2018, https://www.scmp.com/news/hong-kong/health-environment/article/ 2131642/why-hong-kongs-ban-ivory-trade-such-big-deal (accessed on 18 July 2018).

12. Pamela Boykoff, Ivan Watson, "Undercover video exposes Hong Kong's illegal ivory trade," CNN, 21 October 2015, https://edition.cnn.com/2015/10/21/asia/hong-kong-illegal-ivory-trade/ (accessed on 25 July 2018).

13. Ernest Kao, "Why Hong Kong's ban on ivory trade is such a big deal," art cit.

14. Legislative Council, https://www.legco.gov.hk/yr16-17/english/panels/ea/agenda/ea20170606ag-app.htm\#attend (accessed on 27 July 2018).

15. Ernest Kao, "Why Hong Kong's ban on ivory trade is such a big deal," art. cit.; Ernest Kao and Danny Lee, "Controversial ivory trade to continue for five more years before full ban imposed," South China Morning Post, 21 June 2016, https://www.scmp.com/news/hong-kong/health-environment/article/1978211/controversial-ivory-trade-continue-five-more-years (accessed on 27 July 2018).

16. Yang Wanli and Edith Mutethya, "Halting ivory," China Daily, 26 May 2018, http://www. chinadaily.com.cn/a/201805/26/WS5b0838f5a31001b82571c664.html (accessed on 24 July 2018).

17. Poon Pak Lam 潘柏林, “港府擬立法5年後禁賣象牙” (Gang fu ni lifa wu nian hou jin mai xiangya, The Hong Kong government intends to legislation the banning of ivory trading within 5 years), Apple Daily, 22 December 2016, https://hk.news.appledaily.com/local/daily/article/2016 1222/19873400 (accessed on 24 July 2018); Elson Tong, "Traditional art or brutal industry? LegCo panel debates plan to phase out ivory trade by 2021," Hong Kong Free Press, 28 March 2017, https://www.hongkongfp.com/2017/03/28/traditional-art-brutal-industrylegco-panel-debatesplan-phase-ivory-trade-2021/ (accessed on 19 July 2018).

18. According to David M. Baker, a member of the Conservation Forensics Lab at the University of Hong Kong. Personal communication, 2017 
stocks that have been seized (in 2014 in Hong Kong and mainland China). These measures seem, however, to be making the substance scarcer and hence are increasing the value of ivory through speculation ('T Sas-Rolfes et al. 2014). Yet since the announcement of the ban in mainland China in 2015, a gradual lowering of the price of illegal raw ivory has been reported (19) (Martin and Vigne 2017). It remains to be seen if poaching will also ease.

These questions thus remain in suspense in the media's treatment of the reform, and the trade ban presented as the remedy for conserving African elephants seems to be merely one stage in this fight. But it should be acknowledged that it does have a strong symbolic value.

\section{The main stress points: The transition period and compensation}

Certain aspects of the ban are treated in some depth in the articles. A transition period of five years has been decreed (until 2021), enabling craftsmen and ivory traders to deplete their stock. The legislative and wildlife protection bodies were hoping of reducing this "period of grace" to two years, justifying the speed of action. (20) But the original deadline has been kept, first of all out of concern for "justice and equity," since the stocks of the craftsmen and traders are owned by them, and they have a licence to exploit them. This is all the more relevant in that the government has authorised the importation of old ivory by foreign countries. (21) Secondly, as the government cannot legally revoke the licences, there will simply be a process of gradual non-renewal. (22)

The second stress point concerns compensation. It is unlikely that the craftsmen and traders will deplete their stocks before 2021, according to a study of the AFCD that acknowledges the low level of trading activity in legal stock since 2016. ${ }^{(23)}$ They therefore considered themselves to have been unfairly deprived of their private property, as guaranteed by the fundamental law, and have made claims for compensation worth several billion Hong Kong dollars for the likely loss of their stock that had been built up in all legality (estimated at between $64^{(24)}$ and 111 tonnes (25) in 2017). But their demands have been rejected on the grounds that it would give a poor image of the government of Hong Kong buying ivory, and that it could favour poaching in the substance, which would be taken to Hong Kong to profit from compensation. (26)

While the corpus of articles allowed each actor in the public debate to establish their case, it is fair to say that the views of institutions for the protection of wildlife seem to have been given the greatest coverage by the press. For example, Hong Kong Free Press has published articles written by representatives of WildAid, (27) and there is regular reporting of their actions in raising public awareness. ${ }^{28)}$ Conversely, certain ideas (whether good or bad) in favour of the craftsmen and traders do not receive much coverage at all; nor does the idea to create outlets for the not-for-profit sale of ivory within a closed network, the profits of which would go to the protection of elephants. ${ }^{(29)}$ Similarly, the future of the unsold stock at the end of the transition period is not broached in these articles. The meagre exposure given to the views of craftsmen and traders can be explained by the fact that there are not many of them (fewer than 500); ${ }^{(30)}$ that they are in the olderage bracket and therefore have a poor command of the codes of communication, particularly when it comes to the visual media; and that they are not visible in social media and prefer to express themselves in Mandarin or Cantonese. Furthermore, their public image has been tarnished by the fraud- ulent actions of certain individuals. (31) Finally, their situation does not seem to have affected either public opinion or a majority of the members of LegCo or the press.

\section{The issue of cultural heritage}

The gradual disappearance of knowledge and know-how about ivory carving in Hong Kong has not really been addressed in these articles. Some pieces concerning the ban in mainland China deal with these matters, in which they refer to the difficulty of transferring the technique of carving to other materials. Mammoth ivory is mentioned, but the issue of the similarity of the technique is a divisive one. Some craftsmen are also of the view that this solution is not sustainable insofar as the stock of mammoth tusks in the frozen earth is in danger of being exhausted. (32)

One article in relation to Hong Kong explains that the issue of artistic and cultural heritage was raised during the debates in the legislature. Its title,

19. Emily Tsang, "Hong Kong approves elephant ivory ban in landslide vote," South China Morning Post, 31 January 2018, https://www.scmp.com/news/hong-kong/health-environment/article/ 2131433/hong-kong-approves-elephant-ivory-ban-landslide (accessed on 18 July 2018); "It's the beginning of the end for ivory in China," China Daily, 2 January 2018, http://www. chinadaily.com.cn/a/201801/02/WS5a4ad56ba31008cf16da48da.html (accessed on 19 July 2018).

20. Kris Cheng, "Cov't says shortening ivory ban's 5-year grace period may be challenging," Hong Kong Free Press, 28 June 2016, https://www.hongkongfp.com/2016/06/28/govt-says-shorteningivory-bans-5-year-grace-period-may-be-challenging/ (accessed on 19 July 2018).

21. Christy Leung "'Need for action beyond dispute': Britain's shameful ivory trade set to end with total ban proposed," South China Morning Post, 7 October 2017, https://www.scmp.com/news/ world/europe/article/2114365/need-action-beyond-dispute-britains-shameful-ivory-trade-setend (accessed on 18 July 2017).

22. Ernest Kao, "Five years to ban Hong Kong ivory trade is too long, lawmakers argue," South China Morning post, 28 June 2016, https://www.scmp.com/news/hong-kong/health-environment/article/1982292/five-years-ban-hong-kong-ivory-trade-too-long (accessed on 12 July 2018).

23. Ernest Kao, "Why Hong Kong's ban on ivory trade is such a big deal," art cit.

24. Ibid.

25. Poon Pak Lam 潘柏林, “施政報告一前瞻:修例禁象牙買賣? 港商改售長毛象牙避監管” (Shizheng baogao—qianzhan:Xiu li jin xiangya maimai? Gang shang gai shou changmao xiangya bi jianguan, Legal prospects. A revision of the law banning the ivory trade? The traders are adamant that they sell mammoth tusks to avoid surveillance), China Daily, 10 January 2016, https://hk.news.appledaily.com/local/realtime/article/20160110/54629083 (accessed on 24 July 2018).

26. Kris Cheng, "No compensation for Hong Kong's ivory traders ahead of total ban, says environment deputy," Hong Kong Free Press, 6 September 2017, https://www.hongkongfp.com/2017/09/06/nocompensation-hong-kongs-ivory-traders-ahead-total-ban-says-environment-deputy/ (accessed on 19 July 2018).

27. Peter Knights, "Hong Kong's ivory trade: When the buying stops, the killing can stop too," Hong Kong Free Press, 27 March 2017, https://www.hongkongfp.com/2017/03/27/hong-kongs-ivorytrade-buying-stops-killing-can-stop/ (accessed on 19 July 2018); Gavin Edwards, "A message from African rangers to Hong Kong: End the ivory trade, because our bodies are on the line," Hong Kong Free Press, 5 June 2017, https://www.hongkongfp.com/2017/06/05/message-african-rangershong-kong-end-ivory-trade-bodies-line/ (accessed on 19 July 2018).

28. Karen Cheung, "Environmentalists protest outside Legislative Council urging lawmakers to support ivory ban," Hong Kong Free Press, 6 September 2017, https://www.hongkongfp.com/2017/ 09/06/environmentalists-protest-outside-legislative-council-urging-lawmakers-support-ivoryban/ (accessed on 19 July 2017).

29. Ho Lok-Sang, "Conservationist sale better choice," China Daily, 20 June 2017, http://www.chinadaily.com.cn/hkedition/2017-06/20/content_29808927.htm (accessed on 19 July 2018).

30. In 2014, according to the Secretary for the Environment, 447 people obtained a licence authorising the possession of ivory (Hong Kong Government, Press Release 2014; Wong 2018). One article puts forward the number of 470 ( 370 wholesalers granted licence and 100 artisans/craftsmen). Ernest Kao, "Why Hong Kong's ban on ivory trade is such a big deal," art cit.

31. Vivienne Zeng, "'I need to eat rice': Ivory trader denies wrongdoing as LegCo debates combating wildlife smuggling," Hong Kong Free Press, 2 December 2015, https://www.hongkongfp.com/ 2015/12/02/i-need-to-eat-rice-ivory-trader-denies-wrongdoing-as-legco-debates-combatingwildlife-smuggling/ (accessed on 19 July 2018).

32. Zheng Caixiong, "Ivory carvers worry skills may be lost," China Daily, 16 January 2018, http://www.chinadaily.com.cn/regional/2018-01/16/content_35512231.htm (accessed on 24 July 2018); Yang Wanli and Edith Mutethya, "Halting ivory," art cit. 
"Traditional art or brutal industry? (...)," seems to explore this area, but remarkably the content does not present any new element that would enable one to understand the heritage issues at stake. ${ }^{(33)}$ In fact, the know-how of ivory carving is an ancestral matter in mainland China (Cox 1946). It was imported to Hong Kong as early as the 1940s, and since 2014 has been on Hong Kong's cultural heritage register as something to be preserved, in line with the application of the UNESCO Convention for the Preservation of Immaterial Cultural Heritage (2003). (34) But it does not appear on the 2017 official list, which may perhaps be seen as one of the repercussions of the reform. (35) These considerations bring into focus the predominance of the preservation of natural heritage over cultural heritage, a recurrent issue in both Hong Kong and mainland China (for example, in the case of shark fins ${ }^{(36)}$ or pangolin scales $\left.{ }^{(37)}\right)$.

\section{Conclusion}

Ever since the adoption of the law in January 2018 largely banning ivory trading in elephant ivory in Hong Kong, the subject has remained in the news through regular seizures by customs. ${ }^{(38)}$ This foregrounding of the subject of ivory trading has brought about an upsurge of interest in the press in the fate of Asian elephants, which were conspicuous by their absence in articles dealing with the reform. We learn, for example, that they are subject to poaching, not for their tusks, but rather for their skins, trafficking that is thought to have decimated the elephant population in Myanmar. ${ }^{(39)}$ While the great majority of articles about the reform carried out in Hong Kong has focused attention on the subject of elephants and ivory, this period has also given rise to a series of articles on the trafficking of other species, for example donkey skins in mainland China, ${ }^{(40)}$ the intensive trade in which is sometimes compared to that in ivory. ${ }^{(41)}$ This linguistic element is certainly aimed at alerting the reader to the urgency of the situation. The elephants and their tusks, as with rhinoceros' horns and shark fins, have thus become emblematic species in the fight against trafficking. Moreover, the logo of the CITES features an elephant. However, this should not lead one to forget that they represent only one part of the global trafficking in animal and vegetal species. ${ }^{(42)}$ Likewise, while the regulation of trade is picked up by the press and wildlife protection bodies as the best means of limiting trafficking, it still remains the case that the human, technical, and scientific resources available to states are often lacking. The extent of trafficking is so prodigious that alternative initiatives to those of states are being put in place, as for example the first online global coalition against trafficking in wildlife. On 7 March 2018 in San Francisco this coalition brought together 21 e-commerce, technology, and social networking companies across several continents (including WWF, IFAW, TRAFFIC, and Google) in order to take steps to put an end to online species trafficking. These measures for regulating trade, which aim to have a direct impact on trafficking, may see their effects diminished as long as the species remain goods with a monetary value. While an improvement in the trend is to be hoped for, particularly through education and the raising of awareness of the need to maintain biodiversity for the survival of the human race itself (the case of insects is revealing), it is unfortunately very unlikely that the trend will be reversed, especially in a context of increasingly unequal distribution of wealth throughout the world. It is this context that feeds, maintains, and perpetuates the existence of organised networks that are at the source of both poaching and illegal wildlife trade.
I Translated by Peter Brown.

Claire Bouillot is a PhD student in Anthropology, French Centre for Research on Contemporary China, Hong Kong, School for Advanced Studies in the Social Sciences, Marseille, France

(claire.bouillot@ehess.fr).

33. Elson Tong, "Traditional art or brutal industry? LegCo panel debates plan to phase out ivory trade by 2021," art cit. See also, “非洲管理員守護大象遭射殺 象牙商會斥政府禁售毀中華文化" (Feizhou guanliyuan shouhu daxiang zao shesha xiangya shanghui chi zhengfu jin shou hui zhonghua wenhua, African officials prevent the slaughter of elephants. The Chamber of Commerce denounces the government ban which would destroy Chinese culture), Apple Daily, 6 June 2017, https://hk.news.appledaily.com/local/realtime/article/20170606/56791341 (accessed on 24 July 2018).

34. "The Hong Kong cultural heritage list," South China Morning Post, 17 June 2014, https://www.scmp.com/news/hong-kong/article/1534799/over-500-hong-kong-traditions-mustbe-safeguarded-under-un-convention (accessed on 26 July 2018); Denise Tsang, Johnny Tam, and Olga Wong, "The 480 things that represent Hong Kong's culture: list unveiled after seven years' work," South China Morning Post, 17 June 2014, https://www.scmp.com/news/hong-kong/article/1534746/cantonese-opera-dim-sum-and-diwali-hong-kong-lists-its-cultural (accessed on 26 July 2018).

35. Leisure and Cultural Services Department, https://www.lcsd.gov.hk/CE/Museum/ICHO/en_US/ web/icho/the_representative_list_of_hkich.html (accessed on 26 July 2018).

36. Kylie Knott, "Where battle to curb shark fin consumption is being won and lost, and why trade has to stop - new research," South China Morning Post, 17 September 2018, https:// www.scmp.com/lifestyle/food-drink/article/2164272/where-battle-curb-shark-fin-consumptionbeing-won-and-lost-and (accessed on 21 September 2018).

37. Karen Zhang, "Consider alternatives to pangolin scales, traditional Chinese medicine professors urge at conservation conference in Hong Kong," South China Morning Post, 6 September 2018, https://www.scmp.com/news/hong-kong/health-environment/article/2162999/consider-alternatives-pangolin-scales-traditional (accessed on 21 September 2018).

38. Danny Mok, "HK\$2.7 million worth of ivory seized by Hong Kong customs in joint operation with mainland Chinese authorities," South China Morning Post, 4 July 2018, https:// www.scmp.com/news/hong-kong/hong-kong-law-and-crime/article/2153656/hk27-millionworth-ivory-seized-hong-kong (accessed on 30 July 2018).

39. Agence France-Presse, "No elephant is safe: China's online market for animal's skin has decimated Myanmar population," South China Morning Post, 24 April 2018, https://www.scmp.com/ news/asia/southeast-asia/article/2143125/no-elephant-safe-chinas-online-market-animals-skinhas (accessed on 30 July 2018).

40. Sidney Leng, "Donkey forum in China to address thinning herd as demand for skins soars," South China Morning Post, 15 August 2017, https://www.scmp.com/news/china/policies-politics/article/2106913/china-plots-hi-tech-path-leader-world-donkey-industry (accessed on 30 July 2018).

41. A China in Africa Podcast, "Donkey Skin Is the New Ivory," China File, 21 March 2017, http://www.chinafile.com/china-africa-project/donkey-skin-new-ivory (accessed on 30 July 2018).

42. The NGO TRAFFIC regularly publishes numerous reports of studies on species trafficking. See https://www.traffic.org/publications/ (accessed on 26 October 2018). 


\section{References}

'T SAS-ROLFES, Michael, Brendan MOYLE and Daniel STILES. 2014. "The Complex Policy Issue of Elephant Ivory Stockpile Management." Pachyderm 55(January-June 2014): 62-78.

BARBIER, Edward B., Joanne C. BURGESS, Timothy M. SWANSON and David W. PEARCE. 2009. Elephants, Economics and Ivory. London: Earthscan.

BENNETT, Elizabeth L. 2015. "Legal Ivory Trade in a Corrupt World and its Impact on African Elephant Populations." Conservation Biology 29(1): 5460.

The Executive Council of Hong Kong. 2014. LCQ2: Ivory Trade. https://www.info.gov.hk/gia/general/201406/04/P201406040449.htm (accessed on 26 October 2018).

CORNELISVAN KOOTEN, G. 2008. "Protecting the African Elephant: A Dynamic Bioeconomic Model of Ivory Trade." Biological Conservation 141: 2012-22.

COX, Warren Earle. 1946. Chinese Ivory Sculpture. New York: Bonanza Books.

GAO, Yufang. 2014. "Elephant Ivory Trade in China: Comparing Different Perspectives." The Bulletin of the Yale Tropical Resources Institute 32-33: $101-7$.
KNIGHTS, Peter, Alex HOFFORD, A. ANDERSSON and D. CHENG. 2015. The Illusion of Control: Hong Kong's Legal Ivory Trade. San Francisco, CA: WildAid.

MARTIN, Esmond, and Lucy VIGNE. 2015. Hong Kong's Ivory, More Items for Sale than in any Other City in the World. Nairobi: Save The Elephants.

PANG, Ka-lai Karie. 2015. Ivory Demand Survey. University of Hong Kong, Social Sciences Research Centre, Public Opinion Programme.

THOULESS, C.R., H.T. DUBLIN, J.J. BLANC, D.P. SKINNER, T.E. DANIEL, R.D. TAYLOR, F. MAISELS, H. L. FREDERICK and P. BOUCHE. 2016. African Elephant Status Report 2016: An Update from the African Elephant Database. Occasional Paper Series of the IUCN Species Survival Commission, No. 60 IUCN / SSC Africa Elephant Specialist Group. IUCN, Gland, Switzerland.

VIGNE, Lucy, and Esmond MARTIN. 2017. Decline in the Legal Ivory Trade in China in Anticipation of a Ban. Nairobi: Save The Elephants.

WITTEMYER, George, Joseph M. NORTHRUPA, Julian BLANC, lain DOUGLAS-HAMILTON, Patrick OMONDI and Kenneth P. BURNHAM. 2014. "Illegal Killing for Ivory Drives Global Decline in African Elephants." PNAS 111(36): 13117-21.

WONG, Rebecca Wing Yee. 2018. "Do you Know Where I Can Buy Ivory? The Illegal Sale of Worked Ivory Products in Hong Kong." Australian \& New Zealand Journal of Criminology 51(2): 20420. 